\title{
Permutational isomers on a molecular skeleton with neighbor-excluding ligands
}

\author{
D. J. Klein · A. Ryzhov • V. Rosenfeld
}

Published online: 20 December 2008

(C) Springer Science+Business Media, LLC 2008

\section{Erratum to: J Math Chem \\ DOI 10.1007/s10910-008-9461-9}

The second author's name was misspelled in the original version. The correct spelling is A. Ryzhov.

The online version of the original article can be found under doi:10.1007/s10910-008-9461-9.

D. J. Klein $(\varangle) \cdot$ A. Ryzhov · V. Rosenfeld

Texas A\&M University, Galveston, TX 77553, USA

e-mail: kleind@tamug.edu 